\title{
Tariff Dispersion and Trade Negotiations
}

\section{Citation}

Cooper, Richard Newell. 1964. Tariff dispersion and trade negotiations. Journal of Political Economy 72(6): 597-603.

\section{Published Version}

doi:10.1086/258966

\section{Permanent link}

http://nrs.harvard.edu/urn-3:HUL.InstRepos:13580987

\section{Terms of Use}

This article was downloaded from Harvard University's DASH repository, and is made available under the terms and conditions applicable to Other Posted Material, as set forth at http:// nrs.harvard.edu/urn-3:HUL.InstRepos:dash.current.terms-of-use\#LAA

\section{Share Your Story}

The Harvard community has made this article openly available.

Please share how this access benefits you. Submit a story.

\section{Accessibility}




\title{
TARIFF DISPERSION AND TRADE NEGOTIATIONS ${ }^{1}$
}

\author{
RICHARD N. COOPER \\ Yale University
}

$\mathrm{I}^{\mathrm{N}}$ INTERNATIONAL tariff negotiations "reciprocity" has always been a vague but important guiding principle. In the item-byitem tariff negotiations that have taken place to date, "reciprocity" on the entire negotiation was insured by reaching a reciprocal bargain on each particular item; and where reciprocity was obviously not obtained on any one bargain, it could be consciously restored in others. Under these circumstances, the over-all characteristics of a country's tariff structure were unimportant for the outcome of the negotiations.

Now that consideration is being given to sweeping, across-the-board reductions in tariffs, the traditional method for insuring reciprocity is no longer available. The proposed tariff reduction must be looked at globally, and the characteristics of the entire tariff structure take on a new relevance to the process of mutual tariff reduction. This has been recognized in the revived interest in measuring national tariff averages and in the recent debate between the United States and the European Economic Community (EEC) over the high dispersion of U.S. tariff rates. ${ }^{2}$

The discussion that follows examines the implications for the effect of tariff reduction

${ }^{1}$ I am grateful to Robert Aliber, Bela Balassa, James Friedman, and Harry Johnson for helpful comments on an earlier version of this paper.

2 The problem of measuring "tariff levels" has a long and distinguished if inconclusive history. See, for example, Gottfried Haberler, The Theory of International Trade (London: Wm. Hodge \& Co., 1936), pp. 355-59; Jacob Viner, "The Measurement of the 'Height' of Tariff Levels," in International Economics (Glencoe, Ill.: Free Press, 1951), pp. 16168; E. Lerdau, "On the Measurement of Tariffs: The U.S. over Forty Years," Economia Internationale, $\mathrm{X}$ (1957), 232-47. The method of analysis suggested here bypasses some of the thorny issues raised in this literature. on imports of two features of the tariff structure: the mean and the standard deviation of tariff rates. Other characteristics, such as skewness or the number of tariff nodes, may also be important; but tariff dispersion is currently in the limelight, ${ }^{3}$ and it is of some interest to isolate its effect on reciprocity in trade negotiations.

\section{RECIPROCITY IN TRADE NEGOTIATIONS}

The "gains" from tariff reductions are presumably measured, in our productionoriented world, by the expected increases in exports which result. "Concessions" are the price which must be paid in higher imports. A fair, "reciprocal" reduction in tariffs in bilateral negotiations can be defined as one for which there are equivalent increases in imports into both bargaining partners. ${ }^{4}$ It

${ }^{3}$ In the preparatory negotiations for the so-called "Kennedy Round" of tariff reductions, this has also been called the "high-low" problem and the problem of "tariff disparities." Lately the latter term has taken on a specific and quite different meaning, viz., large differences between the U.S. and EEC duties on the same commodity. Such "disparities" could exist even if the two tariff structures had the same dispersion. This new meaning seems to have been adopted largely for tactical and political reasons; tariff dispersion raises a more interesting theoretical issue, and will alone be considered here.

There are several possible measures of dispersion. The standard deviation has the advantage of being commonly used and well understood; and it weights heavily tariffs far from the average, as would seem consistent with European concern about the wide dispersion in U.S. tariffs.

4 "Reciprocity" in tariff negotiations has never been officially defined, but the State Department has said that in striking "a mutually satisfactory balance of concessions" weight is given to the amount of existing trade affected, the amount of trade expansion likely to be stimulated, the depth of the tariff cuts, the timing of the tariff cuts, and other (unnamed) factors. It is common practice, after the completion of tariff negotiations, to cite the total 
is worth asking what conditions need to be satisfied if this version of "reciprocity" is to obtain under across-the-board tariff reductions when there are substantial differences in the tariff structures of the bargaining partners. For simplicity bilateral negotiations between two trading partners will be assumed. ${ }^{5}$

The requirement for reciprocity in bilateral negotiations can be set out formally as

$$
\Delta M_{1}=\Delta M_{2},
$$

where $\Delta M$ represents the increase in total imports into the subscript country due to the tariff reductions. I assume that for the sort of tariff change under consideration cross-product effects are negligible, and that tariff reductions in the likely range will not influence export supply prices, which for convenience are set equal to unity for all commodities. Under these assumptions,

$$
\begin{aligned}
\Delta M=\sum_{i=1}^{n} \frac{\partial D_{i}}{\partial P_{i}} \Delta P_{i} \\
=\sum_{i=1}^{n} M_{i} \epsilon_{i}\left(\frac{t_{i}}{1+t_{i}}\right) \frac{\Delta t_{i}}{t_{i}},
\end{aligned}
$$

where $D_{i}=D_{i}\left(P_{i}\right)$ is the import demand for commodity $i, P_{i}$ is the domestic price of $i$ to the importing country's consumers (including tariff), $M_{i}$ is the importation of $i$ before the tariff reduction, $\epsilon_{i}$ is the price

value of existing trade on which concessions were given and received, but this is presumably shorthand for a more complicated balance of advantages.

In multilateral across-the-board tariff negotiations, one measure of "reciprocity" might be equal percentage increases in the imports of all the negotiating countries, although this would not, of course, guarantee that the exports of all participants would rise proportionately. In a two-country world with balanced trade, this measure of reciprocity is the same as the definition suggested here.

${ }^{5}$ While in principle the Kennedy Round tariff negotiations will be multilateral, in fact the key bargaining rules will be struck between the United States and the EEC. Nonetheless, both parties will watch third-country effects closely; the most important of these third parties will be the United Kingdom and its European Free Trade Associates. elasticity of demand for imports of $i$ in the vicinity of $M_{i}, t_{i}$ is the initial ad valorem tariff imposed on $i, \Delta t_{i}$ is the change in the tariff rate, and $n$ is the number of commodities. $^{6}$

Attention in the Kennedy Round of tariff negotiations is on a uniform, across-theboard tariff cut of 50 per cent. For convenience, set

$$
N_{i}=M_{i} \epsilon_{i} \quad \text { and } \quad T_{i}=\frac{t_{i}}{1+t_{i}} .
$$

Therefore, ${ }^{7}$

$\Delta M=\frac{\Delta t}{t} \sum_{i=1}^{n} N_{i} T_{i}$, where $\frac{\Delta t}{t}=0.5$.

THE EFFECT OF DISPERSION ON RECIPROCITY

We can think of a country's tariff schedule as a frequency distribution of tariff rates with a mean and standard deviation. It is easy to show from equation (3) that ${ }^{8}$

$$
\Delta M=n \frac{\Delta t}{t}\left(\langle N\rangle\langle T\rangle+r_{N T} S_{N} S_{T}\right),
$$

where $\langle N\rangle$ and $\langle T\rangle$ are the mean values of $N_{i}$ and $T_{i}$, respectively, $S_{N}$ and $S_{T}$ are their standard deviations, and $r_{N T}$ is the correlation between them.

Bias $(B)$ in the negotiations will result if

$$
\begin{aligned}
B=\Delta M_{1} & -\Delta M_{2} \\
& =n_{1}\left(\left\langle N_{1}\right\rangle\left\langle T_{1}\right\rangle+r_{N T} S_{N} S_{T}\right) \\
& -n_{2}\left(\left\langle N_{2}\right\rangle\left\langle T_{2}\right\rangle+\rho_{N T} \sigma_{N} \sigma_{T}\right)
\end{aligned}
$$

differs from zero (where subscripts designate the countries and Greek letters are used for

${ }^{8}$ If $t_{i}$ is fully protective, $M_{i}=0$ and $\epsilon_{i}$ is not defined. But this formal difficulty is overcome if we understand $\epsilon_{i}$ to be the arc elasticity-dependent, of course, on the size of the tariff cut.

${ }^{7}$ I follow the convention of treating $\epsilon_{i}$ as positive rather than negative, so that a tariff cut also enters with a positive sign, leading to an increase in $M$.

$$
\begin{aligned}
&{ }^{8} \Sigma N_{i} T_{i}= \Sigma\left[\left(N_{i}-\langle N\rangle\right)\right. \\
&+\langle N\rangle]\left[\left(T_{i}-\langle T\rangle\right)+\langle T\rangle\right]=n\langle N\rangle\langle T\rangle \\
&+\Sigma\left(N_{i}-\langle N\rangle\right)\left(T_{i}-\langle T\rangle\right) \\
&=n\left[\langle N\rangle\langle T\rangle+r_{N T} S_{N} S_{T}\right] .
\end{aligned}
$$


country 2). The bargaining will be "unfair" to country 1 if $B>0$, and to country 2 if $B<0 .{ }^{9}$ It can be seen from equation (4) that tariff dispersion can indeed influence the impact of a uniform tariff cut on imports. Greater tariff dispersion in country 1 $\left(S_{T}>\sigma_{T}\right)$ will tend to bias the outcome of tariff bargaining in favor of that country (that is, its imports will tend to rise less than those of country 2) if ${ }^{10}$

$$
r_{N T} S_{N} S_{T}<\rho_{N T} \sigma_{N} \sigma_{T} .
$$

Greater tariff dispersion in country 1 will tend to bias the outcome against country 1 if inequality (6) is reversed. Note that if $r_{N T} S_{N}=\rho_{N T} \sigma_{N}$, condition (6) holds only if the correlations between $N_{i}$ and $T_{i}$ are negative, that is, if high tariffs tend to be associated with low values of import sensitivity to price reduction $\left(M_{i} \epsilon_{i}\right)$.

Substituting $M_{i} \epsilon_{i}$ for $N_{i}$, condition (5) for bias can be closely approximated by ${ }^{11}$

$$
\begin{aligned}
B & =n_{1}\left(\left\langle M_{1}\right\rangle\left\langle\epsilon_{1}\right\rangle\left\langle T_{1}\right\rangle+\left\langle M_{1}\right\rangle \boldsymbol{r}_{\epsilon T} S_{\epsilon} S_{T}\right. \\
& \left.+\left\langle\epsilon_{1}\right\rangle \boldsymbol{r}_{M T} S_{M} S_{T}+\left\langle T_{1}\right\rangle \boldsymbol{r}_{\epsilon} S_{\epsilon} S_{M}\right) \\
& -n_{2}\left(\left\langle M_{2}\right\rangle\left\langle\epsilon_{2}\right\rangle\left\langle T_{2}\right\rangle+\left\langle M_{2}\right\rangle \rho_{\epsilon T} \sigma_{\epsilon} \sigma_{T}\right. \\
& \left.+\left\langle\epsilon_{2}\right\rangle \rho_{M T} \sigma_{M} \sigma_{T}+\left\langle T_{2}\right\rangle \rho_{\epsilon M} \sigma_{\epsilon} \sigma_{M}\right) .
\end{aligned}
$$

And condition (6) can be written:

$$
\begin{aligned}
\left(\left\langle M_{1}\right\rangle \boldsymbol{r}_{\epsilon T} S_{\boldsymbol{\epsilon}}+\left\langle\epsilon_{1}\right\rangle \boldsymbol{r}_{M T} S_{M}\right) S_{T} \\
\quad<\left(\left\langle M_{2}\right\rangle \rho_{\epsilon T} \sigma_{\epsilon}+\left\langle\epsilon_{2}\right\rangle \rho_{M T} \sigma_{M}\right) \sigma_{T},
\end{aligned}
$$

since $r_{N T} S_{N} S_{T}$ approximately equals the term on the left-hand side of the inequality and $\rho_{N T} \sigma_{N} \sigma_{T}$ approximately equals the term on the right-hand side.

\section{SOME CONJECTURES ABOUT \\ CORRELATION VALUES}

Interest in condition (8) arises from the debate between American and European negotiators over the effects on reciprocity of higher dispersion in the U.S. tariff struc-

${ }^{9}$ Any bias can, of course, be offset by appropriately different uniform tariff cuts for the two countries.

${ }^{10}$ Assuming $n_{1}=n_{2}$, which would result from use of a common system of tariff classification for the two countries. ture. A number of Europeans have expressed the concern that this higher dispersion would bias uniform tariff reductions in favor of the United States.

In (8), let subscript 1 and Roman letters stand for the United States and subscript 2 and Greek letters stand for the EEC. The EEC contends $S_{T}>\sigma_{T}$ and that this implies the inequality (8). It is clear that condition (8) can be met in a variety of ways, and without some empirical information it is difficult to ascertain whether it will be satisfied. Unfortunately, empirical information on price elasticities of demand for imports is not available in the required detail for all commodities. A careful sampling procedure might provide reliable estimates for the various terms. However, even without such estimates, several conjectures can be made about the terms.

First, it could be plausibly argued that all the correlation coefficients are negligible, that is, that there is no systematic relationship between the height of the tariff, the price elasticity of demand for imports, and the initial value of imports. If this were so, reciprocity would be achieved if $\left\langle M_{1}\right\rangle\left\langle\epsilon_{1}\right\rangle\left\langle T_{1}\right\rangle=$ $\left\langle M_{2}\right\rangle\left\langle\epsilon_{2}\right\rangle\left\langle T_{2}\right\rangle$. Dispersion in the tariff structures would not be relevant. Raising the question of tariff dispersion therefore implies a judgment that tariff levels are significantly correlated with import values or elasticities or both.

It is perhaps natural to assume that tariff heights and imports are inversely correlated. This is certainly true for a single commodity: raising its tariff will reduce import demand. It is less clear why this inverse correlation should obtain for a cross-section of many commodities. Low duties can be as protective as high duties, particularly when they are applied to processing industries where raw materials enter duty-free, as is the case for both the United States and the EEC. Nonetheless, it is commonly believed

$11\langle M\rangle$ and $\langle\epsilon\rangle$ are the average values of $M_{i}$ and $\epsilon_{i}$, respectively, $S_{M}$ and $S_{\epsilon}$ are their standard deviations, and $r_{M \epsilon}$ is the correlation between them. As before, Greek letters are used for country 2. Thirdorder moments have been neglected. 
that high duties tend to restrict imports more than low duties, and an inverse correlation between tariffs and imports seems to have some slight basis in fact. ${ }^{12}$

An inverse correlation between tariff levels and import elasticities might also seem likely. This would especially be true if, as has sometimes been claimed of American tariffs in the past, duties are higher than necessary to provide complete protection. A substantial drop in tariff rates might not stimulate imports at all. Three observations, however, suggest that any inverse correlation between U.S. duties and import elasticities will be weak, if indeed it exists at all.

First, as just mentioned, excess protection can be associated with any level of tariff, not just with high tariffs. A 50 per cent reduction in a 10 per cent tariff on a processing industry requiring only a 5 per cent duty for full protection will not stimulate imports.

Second, the item-by-item approach to tariff negotiations in the past should have assured that excess protection was eliminated on most goods long ago; it is such duties which astute tariff negotiators will be willing to lower first, and it would be surprising if many excessively protective duties have survived the five major postwar trade negotiations. The "peril point" procedure in U.S. preparations for tariff negotiations estimated tariff rates below which imports might seriously threaten particular U.S. industries. Duties were usually reduced to these levels, and sometimes below them. Thus, whatever "water" may have been in the U.S. tariffs should have been largely squeezed out by now.

Third, a lowering of tariffs without any significant rise in imports implies that the protected industries must enjoy high profits; imports do not respond to tariff cuts because producers reduce prices rather than output to meet the additional import competition. But, in fact, high U.S. tariffs, with a few notable exceptions, protect industries in which profits are lower, sometimes much lower, than the average for all U.S. manufacturing. Lower tariffs might well threaten

${ }^{12}$ See Table 1 below. the existence of these industries, not merely their profits.

On the European side, it is less clear what the relation between import elasticities and tariff levels may be. Since the members of the EEC have had no formal procedure such as the "peril-point" hearings to limit effective tariff cuts, and since high European tariffs are not so obviously associated with low-profit industries as is true in the United States, one might conjecture that $\rho_{\epsilon T}<r_{\epsilon T}$. This is especially likely if agricultural products are included. These products are heavily protected by non-tariff barriers to trade on both sides of the Atlantic, so tariff reductions might stimulate very little increase in imports. But U.S. tariffs on agricultural products tend to be lower than tariffs on manufactures, while the opposite is true of the EEC.

As for the correlation between import elasticities and the level of imports, here again the inverse correlation usually assumed (it is implicit, for example, in a linear demand schedule for imports) for a single commodity cannot be transferred to a crosssection of many commodities.

\section{A LIMITED APPLICATION TO U.S.-EEC TARIFF NEGOTIATIONS}

Values for the general characteristics of a tariff schedule will as a rule depend on the system of tariff classification. For example, some product groups (such as textiles in the U.S. tariff schedule) may be entered in great detail, while others might comprise just a few entries. Those entered in detail will get much greater weight in the computation of the mean and standard deviation. One merit of the approach outlined here and expressed in equation (7) is that the over-all result does not depend upon the system of classification, since products entered in the tariff schedule in great detail would be associated with small values of imports. Meaningful comparison of the individual elements of equation (7) - of tariff dispersion, for example-does however depend on the system of classification.

Unfortunately, there are large differences 
between the U.S. tariff schedule, which contains over six thousand items, and the tariff schedule of the EEC, which contains about thirty-three hundred entries. Recently, however, several studies have attempted to reduce these schedules to a common system of classification, based on the Brussels Tariff Nomenclature (BTN) used by many European countries and by the EEC. ${ }^{13}$ Even so, the impossibility of perfect conversion from one tariff classification to another means that the method of reclassification will influence the features of the tariff structure in which we are interested.

Despite this difficulty, I have attempted to show in Table 1 summary data on tariffs and imports for the United States and the EEC. The data are imperfect in two further respects. First, they are computed on the basis of ninety-nine BTN chapters; the "tariff" for each chapter is in fact an average of each chapter's component tariffs weighted by imports. Thus the really high-tariff-lowimport items have to some extent been averaged away. Second, the EEC import data refer to 1959 , when the common external tariff was not actually in effect. ${ }^{14}$ Nevertheless, considerable dispersion exists even at this level of aggregation, and it may be suggestive to see what conclusions can be drawn from it.

\footnotetext{
${ }^{13}$ See Frances K. Topping, Comparative Tariffs and Trade (Supplementary Paper No. 14 [New York: Committee for Economic Development, 1963]). An earlier study by Political and Economic Planning, Atlantic Tariffs and Trade (London, 1959), covered also the United Kingdom and other members of the EFTA, but was limited to industrial products. The PEP study computes tariffs both on the BTN basis and on the basis of the United Nations Standard International Trade Classification. More recently the EEC has published an analysis of industrial tariff structures based on (pre-1961) PEP data for the U.S. and U.K. and on post-1961 reduced tariffs for the EEC (M. Mesnage, "Comparison Statistique du tarif douanier common de la CEE, du tarif des Etats-Unie d'Amerique et du tarif du Royaume-Uni de Grande-Bretagne et de l'Irlande du Nord"' [Brus. sels: Statistical Office of the EEC, 1963]).

${ }^{14}$ EEC spokesmen have argued that its incidence is roughly comparable to that of the four tariff structures it is to replace, but this claim is open to some doubt.
}

It can be seen from Table 1 that the average tariff levels computed here are very close..$^{15}$ The dispersion of the two tariff structures is not very different either, with the United States showing only a slightly higher dispersion. ${ }^{16}$ It is interesting to note, however, that the dispersion of imports is much higher for the EEC than for the United States. The correlation between tariff heights and import value is negative for both the United States and the EEC, as is usually supposed, but small.

If price elasticities of demand for imports are uncorrelated with tariff heights and with existing imports (that is, $r_{\epsilon T}=r_{\epsilon M}=\rho_{\epsilon T}=$

TABLE 1

\section{CHARACTERISTICS OF TARIFFS AND IMPORTS*}

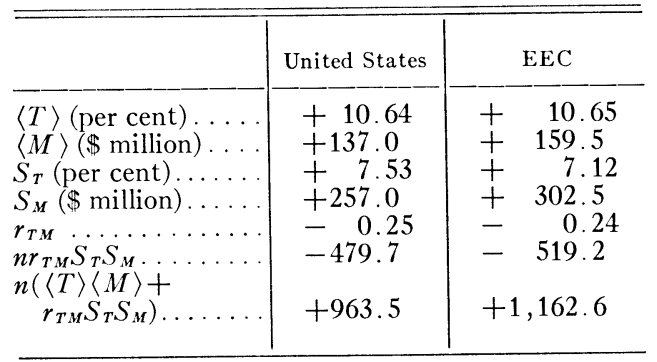

* Based on BTN, chaps. 1-99; 1960 imports for the United States, 1959 for the EEC, excluding intra-EEC trade.

Source: Computed from data in Frances K. Topping, Comparative Tariffs and Trade (New York: Committee for Economic Development, 1963).

$\left.\rho_{\epsilon M}=0\right)$-an assumption which seems plausible-then for $n_{1}=n_{2}=n$ reciprocity requires (from eq. [7], setting $B=0$ ):

$$
\begin{aligned}
n\left\langle\epsilon_{1}\right\rangle & \left(\left\langle T_{1}\right\rangle\left\langle M_{1}\right\rangle+r_{T M} S_{T} S_{M}\right) \\
& =n\left\langle\epsilon_{2}\right\rangle\left(\left\langle T_{2}\right\rangle\left\langle M_{2}\right\rangle+\rho_{T M} \sigma_{T} \sigma_{M}\right) .
\end{aligned}
$$

Since, from Table 1, the term in parentheses for the EEC exceeds that for the United States, the EEC stands to concede a larger increase in imports in bilateral across-theboard bargaining unless $\left\langle\epsilon_{1}\right\rangle$ exceeds $\left\langle\epsilon_{2}\right\rangle$ by

${ }^{15}$ Recalling that $T_{i}=t_{i} /\left(1+t_{i}\right)$, the entries in Table 1 imply an average tariff of 12.3 per cent for both the United States and the EEC.

${ }^{16}$ The averaging involved in using the BTN chapters has presumably reduced U.S. tariff dispersion more than EEC tariff dispersion. 
about 20 per cent. ${ }^{17}$ This is due not to higher U.S. tariff dispersion-indeed the higher import dispersion of the EEC reduces its expected increase in imports-but to a higher total value of EEC imports. ${ }^{18}$

${ }^{17}$ There are two reasons for thinking that $\left\langle\epsilon_{1}\right\rangle$ may in fact exceed $\left\langle\boldsymbol{\epsilon}_{2}\right\rangle$. First, imports are generally smaller in relation to production in the United States than is true of the EEC, so the elasticity of substitution for domestic goods is perhaps, on the average, higher in the United States. Second, there is reason to believe that in establishing the common external tariff, some "excessive" protection was introduced into the EEC tariff structure (see Lawrence Krause, "European Economic Integration and the United States," American Economic Review, LIII [May 1963], 185-96; and my "Discussion," ibid., pp. 201-3).

If $\rho_{\epsilon T}<r_{\epsilon T}$, as I argued above might well be the case, the discrepancy in expected increase in imports would be further reduced.

The presence of intermediate materials such as fuel and metals in the calculation raises a question about the assumption in eq. (2) that cross-elasticities are negligible. A reduction in input prices will shift the import demand schedules of some more highly fabricated products. Tariffs on industrial materials are generally very low or zero, however, so the error introduced will not be great.

${ }^{18}$ If reciprocity were based on equal percentage increases in imports (see n. 4), the outcome of the negotiations would still be biased against the EEC unless the average U.S. elasticity exceeded that of the EEC by about 4 per cent. But for reasons given in the previous footnote, it is very likely that the U.S. clasticity is at least 4 per cent higher than that of the EEC.

Having gone this far with these imperfect data, it is of interest to go a step further and estimate the actual increase in imports to be expected from an across-the-board 50 per cent reduction in tarifis, recalling that

$$
\Delta M=\frac{\Delta t}{t}\langle\epsilon\rangle n\left[\langle T\rangle\langle M\rangle+r_{T M} S_{T} S_{M}\right]
$$

on the assumption $r_{\epsilon T}=r_{\epsilon M}=0$. Here $n=99$ and $\Delta t / t=0.5$. For all imports $\langle\epsilon\rangle$ is probably in range 1.0-2.0. Ball and Marwah, for instance, estimate a composite price elasticity of U.S. demand for imports of 1.3 in the period 1948-58. The price elasticity of U.S. import demand for manufactures, which figure heavily in the U.S.-EEC trade, is 3.5 (see R. J. Ball and K. Marwah, "The U.S. Demand for Imports, 1948-1958," Review of Economics and Statistics, XLIV [November, 1962], 395-401). These estimates combined with the figures in Table 1 suggest an import increase due to Kennedy Round negotiations of $\$ 500-\$ 1,000$ million annually for the
Dispersion in tariff structure constitutes just one difficult issue in the Kennedy Round of tariff negotiations; the other major issue is trade in agricultural products. The EEC holds that these must be given quite separate treatment, and the EEC's discussion of "tariff disparities" is generally meant to apply only to manufactures and raw materials, not to foodstuffs. ${ }^{19}$ The results of recalculation of the parameters in Table 1, excluding foodstuffs, beverages, and tobacco (BTN, chaps. 1-24), are shown in Table 2 .

Here we do find a significantly higher tariff dispersion for the United States than for the EEC, thus tending to reduce the in-

TABLE 2

CHARACTERISTICS OF TARIFFS AND IMPORTS, ExCluding FoOd, BEvERAGES, AND TOBACCO*

\begin{tabular}{|c|c|c|}
\hline & United States & EEC \\
\hline $\begin{array}{l}\langle T\rangle \text { (per cent) } \ldots \ldots \\
\langle M\rangle \text { (\$ million) } \ldots \ldots \\
S_{T}(\text { per cent }) \ldots \ldots \ldots \\
S_{M}(\$ \text { million }) \ldots \ldots \ldots \\
r_{T M} \ldots \ldots \ldots \ldots \\
n r_{T M} S_{T} S_{M} \ldots \ldots \ldots \ldots \\
n\left(\langle T\rangle\langle M\rangle+r_{T M} S_{T} S_{M}\right)\end{array}$ & $\begin{array}{l}+11.79 \\
+146.5 \\
+\quad 7.70 \\
+256.3 \\
-\quad 0.37 \\
-552.3 \\
+744.2\end{array}$ & $\begin{array}{l}+\quad 9.72 \\
+145.1 \\
+\quad 5.98 \\
+339.2 \\
+\quad 0.33 \\
-490.5 \\
+565.1\end{array}$ \\
\hline
\end{tabular}

* Based on BTN, chaps. 25-99.

Source: See Table 1.

crease in U.S. imports that would resuit from a uniform tariff cut $(-552<-490)$.

However, the United States has a higher average tariff on these products, and U.S. and EEC import values are about the same. ${ }^{20}$ The net effect, shown in the last

United States and $\$ 600 \$ 1,200$ million for the EEC. This rise would be spread over five years as tariffs are reduced in stages. Growth in total imports above 1959-60 levels would raise these estimates somewhat.

${ }^{19}$ See, for example, Mesnage, op. cit., who excludes foodstuffs, beverages, and tobacco in his discussion of tariff dispersion.

${ }^{20} \mathrm{It}$ is noteworthy that a higher average tariff tends to increase the rise in imports following a uniform, across-the-board tariff reduction. This is because an equi-percentage reduction in tariffs $\mathrm{im}$ plies a higher percentage reduction in prices (inclusive of tariff) for high tariff items. 
row of Table 2, is a substantially greater prospective increase in U.S. imports despite greater tariff dispersion. This contrasts with the results in Table 1, where the EEC stood to experience a greater rise in imports. Higher average price elasticities for imports into the United States would aggravate the discrepancy here.

The difference between the two sets of figures perhaps helps to explain the great interest of the EEC in excluding agriculture from the across-the-board tariff reductions. EEC insistence on special rules requiring a greater-than-average reduction of the high U.S. tariffs also reflects shrewd bargaining.

\section{SUMMARY}

The shift from item-by-item to acrossthe-board techniques in international tariff bargaining gives an importance to the overall characteristics of national tariff structures which they have hitherto lacked. Preparatory work for the "Kennedy Round" of tariff negotiations has brought public attention to one such characteristic, tariff dispersion, with the European claim that the great dispersion of U.S. tariff rates will place the European Economic Community at an unfair disadvantage unless special rules are adopted for high tariffs. Equation (4) shows that tariff dispersion can indeed influence the impact of across-the-board tariff reductions on imports, and inequalities (6) and (8) show the conditions that must be met if high U.S. tariff dispersion is to hurt the EEC.

Numerical estimation of the parameters in these inequalities cannot be carried out easily. But some highly conjectural and crude empirical evidence presented here fails to support the view that, on balance, higher U.S. tariff dispersion will place the EEC at a disadvantage in the outcome of uniform, across-the-board tariff reductions. ${ }^{21}$

21 Recently it has been alleged that the EEC will suffer a "loss of bargaining power" if there is a uniform 50 per cent tariff reduction, placing the EEC at substantial disadvantage in future negotiations. Halving existing tariffs will reduce over 90 per cent of EEC duties to below 10 per cent, while it will still leave a substantial number of U.S. duties over 20 per cent.

Such a loss in bargaining power by the EEC must imply that in subsequent tariff negotiations the United States would expect to lose so much more than it expected to gain that it would be unwilling to bargain on further reductions. In formal terms, it implies that

$$
\begin{aligned}
\left\langle N_{1}\right\rangle\left\langle T_{1}\right\rangle+r_{N T} S_{N} S_{T} & \\
& >\left\langle N_{2}\right\rangle\left\langle T_{2}\right\rangle+\rho_{N T} \sigma_{N} \sigma_{T}
\end{aligned}
$$

by a substantial margin. But this is precisely the reverse of the condition required for a larger rise in EEC imports than in U.S. imports following the Kennedy Round negotiations. If high U.S. tariff dispersion is to bias the current negotiations against the EEC, $r_{N T} S_{N} S_{T}$ must be smaller than $\rho_{N T} \sigma_{N} \sigma_{T}$. And if current negotiations are biased against the EEC, $\left\langle N_{2}\right\rangle$ would probably exceed $\left\langle N_{1}\right\rangle$ at the start of the next round of negotiations. On both counts the United States should have all the more incentive to enter future negotiations for further tariff reductions. 